\title{
PRODUCTION OF BITUMEN MODIFIED WITH LOW-MOLECULAR ORGANIC COMPOUNDS FROM PETROLEUM RESIDUES. 2. BITUMEN MODIFIED WITH MALEIC ANHYDRIDE
}

\author{
Volodymyr Gunka ${ }^{1}$, Yuriy Prysiazhnyi ${ }^{1}$, Yurii Hrynchuk ${ }^{1}$, Iurii Sidun ${ }^{1}$, \\ Yuriy Demchuk ${ }^{1}$, Olena Shyshchak ${ }^{1}$, Michael Bratychak ${ }^{1, \bigotimes}$
}

https://doi.org/10.23939/chcht15.03.443

\begin{abstract}
The possibility of modification of BND 60/90 bitumen produced at JSC Ukrtatnafta (Kremenchuk, Ukraine) with maleic anhydride has been considered. The effect of maleic anhydride amount, process time and temperature on the operating characteristics of modified bitumen has been studied.
\end{abstract}

Keywords: bitumen, maleic anhydride, modified bitumen.

\section{Introduction}

The road construction has long been a well-studied object. The leaders in this field are the countries of the European Union, the United States, Japan, and Canada. This is confirmed by the quantity, quality and operation life of roads in the above countries. Therefore, all the current trends in the field of road construction are primarily related to ensuring the currently established high quality standards of road construction materials. Solving of this problem is becoming more and more difficult due to either a shortage of raw materials or their high cost.

In Ukraine, the problem of quality of road construction materials is relevant for a long time, which has been unsuccessfully solved for the last few decades. However, over the past 3-4 years, it has become especially acute. This is due to the intensive restoration of existing and construction of new roads using modern world technologies, which is confirmed, for example, by the program "Large Construction" [1].

In this regard, many scientific institutions, laboratories and other specialized institutions in Ukraine are currently working intensively to find and create new high-quality road construction materials, as well as to

\footnotetext{
${ }^{1}$ Lviv Polytechnic National University

12 S.Bandery St., Lviv 79013, Ukraine

mbratychak@gmail.com

(C) Gunka V., Prysiazhnyi Y., Hrynchuk Y., Sidun I., Demchuk Y., Shyshchak O., Bratychak M., 2021
}

improve the quality of existing ones. Lviv Polytechnic National University is no different. The experimental studies in this area are conducted at the Department of Chemical Technology of Oil and Gas Processing. Thus, in [2-6] the production of paving bitumen (PB) modifiers using various by-products of coal coking was studied in detail. It is shown that the physical introduction of synthesized compounds in the PB increases its qualitative values to those required by regulations. Also, within the project "Obtaining of bitumen modified with low molecular organic compounds from petroleum residues" supported by the National Research Fund of Ukraine, scientists of the above Department are conducting research in the direction of petroleum residues and substandard paving bitumen chemical modification with formaldehyde and maleic anhydride to improve its quality. In this regard, the first article in the series [7, 8] is devoted to the peculiarities of petroleum residues modification with formaldehyde. This work deals with the changes in the $\mathrm{PB}$ chemical structure due to the introduction of maleic anhydride (MAH).

The results of available scientific works [9-12] on the chemical reaction of bitumen components and maleic anhydride indicate a positive effect of this modifier on the qualitative characteristics of PB. MAH-bitumen interaction is characterized by complex mechanisms (copolymerization with bitumen molecules [9] or DielsAlder reactions $[10,11])$. Nevertheless, it has been shown that meaningful change of bitumen physical properties are induced by MAH. In this respect Nadkarni et al. [12] studied bitumen containing different amounts of MAH in terms of dynamic mechanical analysis (DMA), melt viscosity, and softening point. The results have shown that the chemical modification of bitumen with MAH improves the cracking resistance at low temperature and cohesive strength at high temperature.

Thus, the study of the chemical modification of paving bitumen with maleic anhydride is relevant in general and it is of particular interest to study the complex effect of this modifier on the qualitative characteristics of 
bitumen. Moreover, it is important to understand the effect of maleic anhydride in regard with bitumen produced in Ukraine.

\section{Experimental}

\subsection{Materials}

The following materials were used for chemical modification of petroleum residues with maleic anhydride:

- BND 60/90 paving bitumen (oxidized bitumen) produced at JSC Ukrtatnafta (Kremenchuk, Ukraine). Its characteristic is given in Table 1, designated as BO-1;
- maleic anhydride, white crystalline powder (used as a process modifier/chemical reagent) of PA grade;

Two types of stone material were used to determine the adhesion of modified petroleum residues to crushed stone:

- crushed stone from natural stone (CS1), fraction 5-20 mm and 20-40 mm, withdrawn at NovogradVolynsky stone crushing plant (Ukraine);

- crushed granite from natural stone of erupted rocks (CS2), fraction 5-20 $\mathrm{mm}$ and $20-40 \mathrm{~mm}$, withdrawn at Mokryansky stone quarry (Ukraine).

The elemental and oxide composition of the stone materials are given in Tables 2-3 and Figs. 1-4.

Table 1

Characteristics of BO-1 bitumen

\begin{tabular}{|c|c|c|}
\hline Index & Value & Standard or Ref. \\
\hline Penetration at $298 \mathrm{~K}, 0.1 \mathrm{~mm}$ & 71 & [15] \\
\hline Softening temperature (R\&B), K & 319 & EN 1427:2018 \\
\hline Ductility at $298 \mathrm{~K}, \mathrm{~cm}$ & $>100$ & [17] \\
\hline Adhesion to CS1 surface, points & 2.5 & \multirow{2}{*}{ [2] } \\
\hline Adhesion to CS2 surface, points & 2.5 & \\
\hline Fraas breaking point, $\mathrm{K}$ & 263 & [16] \\
\hline Plastic range & 329 & {$[2,13]$} \\
\hline Penetration index & -0.65 & [13] \\
\hline \multicolumn{2}{|l|}{ RTFOT } & \multirow{6}{*}{ EN 12607-1:2014 } \\
\hline Change in mass after RTFOT, wt \% & 0.03 & \\
\hline Softening temperature (R\&B) after RTFOT, K & 325.2 & \\
\hline Penetration at $298 \mathrm{~K}$ after RTFOT, $0.1 \mathrm{~mm}$ & 55 & \\
\hline$\Delta \mathrm{R} \& \mathrm{~B}, \mathrm{~K}$ & 6.2 & \\
\hline Residual penetration, $\%$ & 77.5 & \\
\hline
\end{tabular}

Table 2

Elemental composition of crushed stones

\begin{tabular}{|c|c|c|c|c|c|}
\hline \multirow{2}{*}{ Element } & \multirow{2}{*}{ Series } & \multicolumn{2}{|c|}{ CS1 } & \multicolumn{2}{c|}{ CS2 } \\
\cline { 3 - 6 } & & Intensity, rel.units & Concentration, wt \% & Intensity, rel.units & Concentration, wt \% \\
\hline $\mathrm{Al}$ & $\mathrm{K}$ & 295851 & 6.07 & 302097 & 6.16 \\
\hline $\mathrm{Si}$ & $\mathrm{K}$ & 3000151 & 25.45 & 3167423 & 27.01 \\
\hline $\mathrm{K}$ & $\mathrm{K}$ & 71229 & 15.40 & 62447 & 14.47 \\
\hline $\mathrm{Ca}$ & $\mathrm{K}$ & 14977 & 2.73 & 20510 & 3.91 \\
\hline $\mathrm{Ti}$ & $\mathrm{K}$ & 11603 & 0.77 & 6153 & 0.44 \\
\hline $\mathrm{Mn}$ & $\mathrm{K}$ & 6370 & 0.10 & 4516 & 0.08 \\
\hline $\mathrm{Fe}$ & $\mathrm{K}$ & 672667 & 7.08 & 428114 & 4.66 \\
\hline $\mathrm{Zn}$ & $\mathrm{K}$ & 8806 & 0.03 & 6161 & 0.02 \\
\hline $\mathrm{Ga}$ & $\mathrm{K}$ & 5401 & 0.01 & 4395 & 0.01 \\
\hline $\mathrm{Sr}$ & $\mathrm{K}$ & 59667 & 0.03 & 129299 & 0.07 \\
\hline $\mathrm{Zr}$ & $\mathrm{K}$ & 100842 & 0.05 & 52632 & 0.02 \\
\hline $\mathrm{Pb}$ & $\mathrm{L}$ & 7643 & 0.01 & 10160 & 0.02 \\
\hline
\end{tabular}


Table 3

Oxide composition of crushed stones

\begin{tabular}{|c|c|c|c|c|c|}
\hline \multirow{2}{*}{ Compound } & \multirow{2}{*}{ Series } & \multicolumn{2}{|c|}{ CS1 } & \multicolumn{2}{c|}{ CS2 } \\
\cline { 3 - 6 } & & Intensity, rel.units & Concentration, wt \% & Intensity, rel.units & Concentration, wt \% \\
\hline $\mathrm{Al}_{2} \mathrm{O}_{3}$ & $\mathrm{~K}$ & 295851 & 11.47 & 302097 & 11.64 \\
\hline $\mathrm{SiO}_{2}$ & $\mathrm{~K}$ & 3000151 & 54.45 & 3167423 & 57.79 \\
\hline $\mathrm{K}_{2} \mathrm{O}$ & $\mathrm{K}$ & 71229 & 18.55 & 62447 & 17.44 \\
\hline $\mathrm{CaO}$ & $\mathrm{K}$ & 14977 & 3.82 & 20510 & 5.48 \\
\hline $\mathrm{TiO}_{2}$ & $\mathrm{~K}$ & 11603 & 1.28 & 6153 & 0.73 \\
\hline $\mathrm{MnO}_{\mathrm{Fe}_{2} \mathrm{O}_{3}}$ & $\mathrm{~K}$ & 6370 & 0.13 & 4516 & 0.10 \\
\hline $\mathrm{ZnO}_{\mathrm{Ga}}$ & $\mathrm{K}$ & 672667 & 10.12 & 428114 & 6.66 \\
\hline $\mathrm{SrO}_{3}$ & $\mathrm{~K}$ & 8806 & 0.04 & 6161 & 0.02 \\
\hline $\mathrm{KrO}$ & $\mathrm{K}$ & 5401 & 0.02 & 4395 & 0.01 \\
\hline $\mathrm{PbO}$ & $\mathrm{K}$ & 100842 & 0.04 & 129299 & 0.08 \\
\hline
\end{tabular}

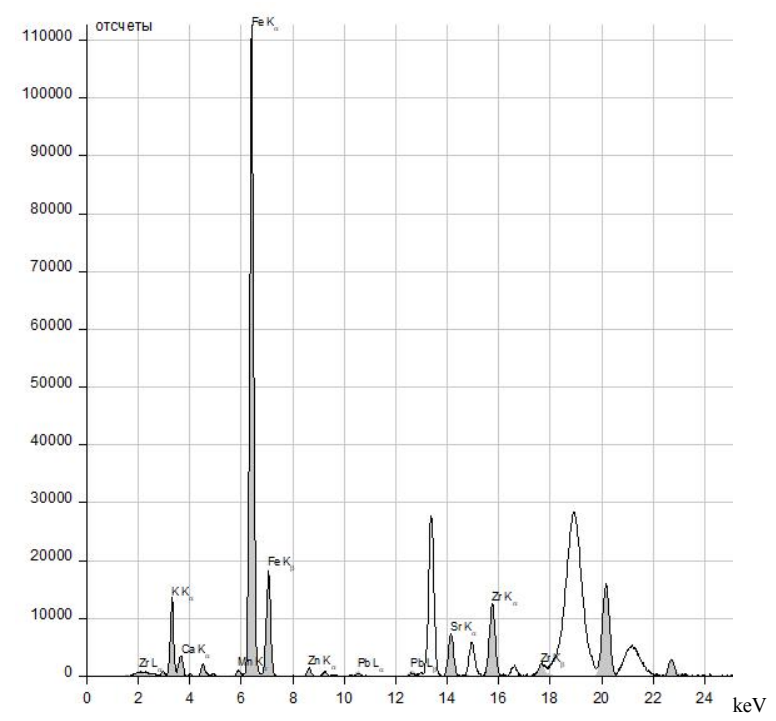

Fig. 1. XRF spectrum (without helium blowing) of CS1 heavy elements

$\mathrm{keV}$

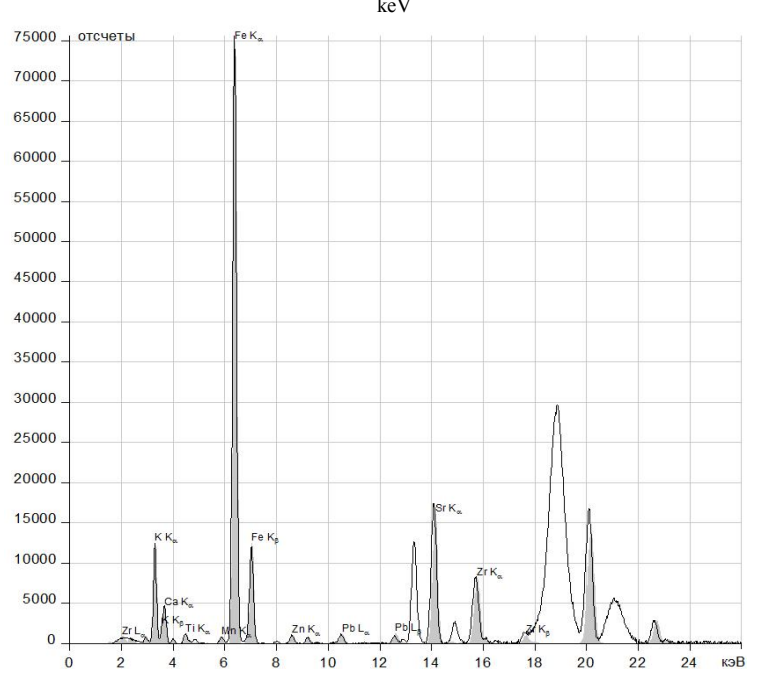

Fig. 3. XRF spectrum (without helium blowing) of CS2 heavy elements

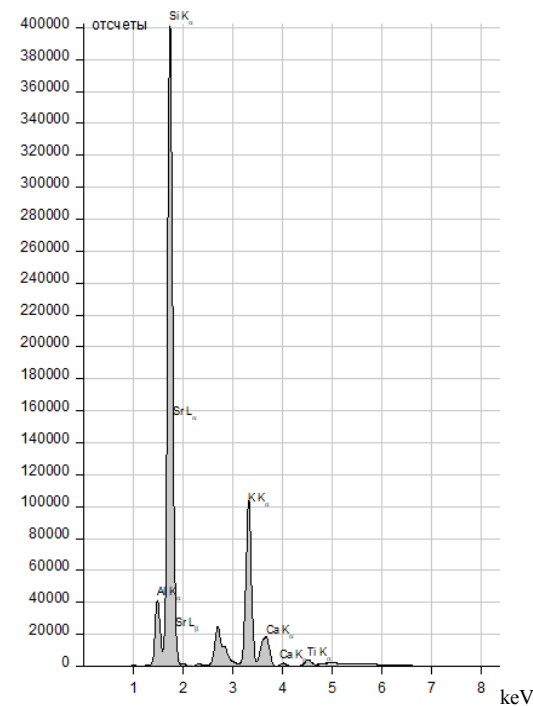

Fig. 2. XRF spectrum (helium blowing) of CS1 light elements

$\mathrm{keV}$

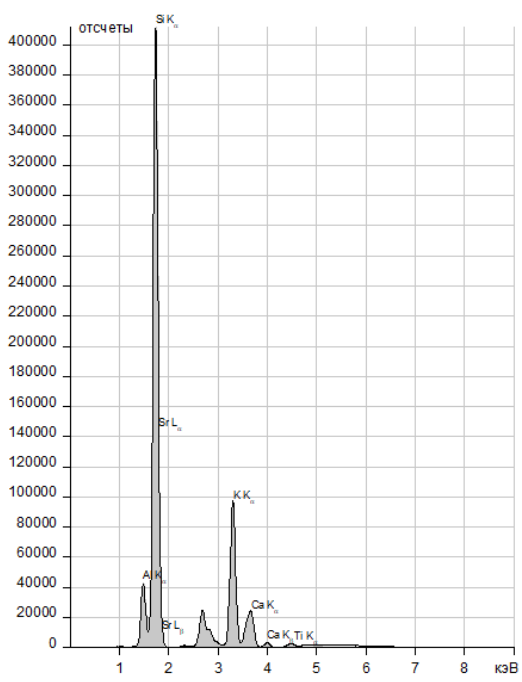

Fig. 4. XRF spectrum (helium blowing) of CS2 light elements 


\subsection{Experimental Procedure}

\subsubsection{Modification of bitumen with maleic anhydride}

Modification with maleic anhydride was carried out at a laboratory setup, the scheme of which is shown in Fig. 5.

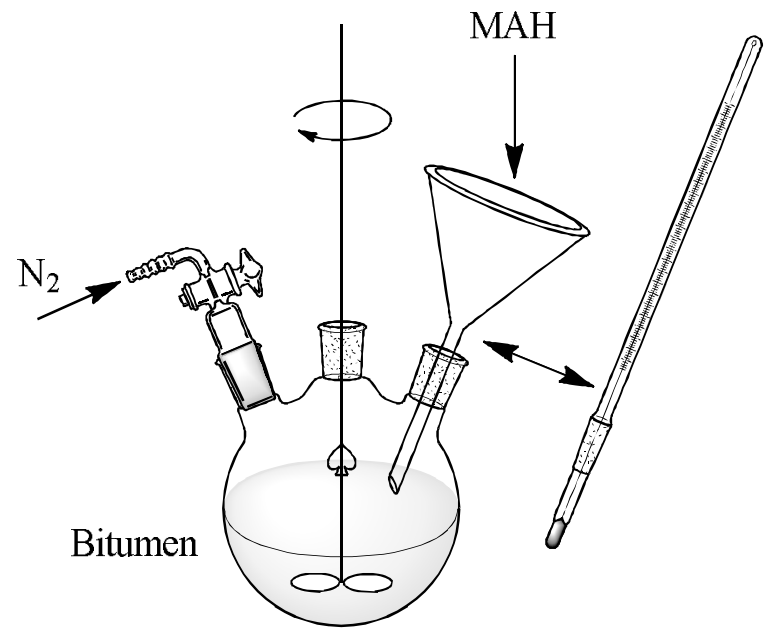

Fig. 5. Experimental setup for chemical modification of bitumen with maleic anhydride

The flask was loaded with bitumen heated to the process temperature. The reaction was carried out under nitrogen atmosphere. Chemical modification was performed under constant stirring. To maintain a constant temperature of bitumen an electric flask heater was used. After setting a constant temperature a dry maleic anhydride was added and the process time was recorded. The modification conditions are shown in Table 4.

\subsection{Methods of Analysis}

\subsubsection{Physico-technological characteristics}

The following physico-technological characteristics of the initial materials and products were determined according to the standard procedures: softening temperature [14]; penetration [15]; Fraas breaking point [16]; ductility [17]; adhesion to crushed stone [2]; plasticity range [2, 13]; penetration index [13].

\subsubsection{Spectral investigations}

XRF analysis of crushed stone was carried out by the Laboratory of Advanced Technologies for the Creation and Analysis of New Compounds and Functional Materials (Lviv Polytechnic National University, Ukraine) using ElvaX Light SDD spectrometer (Elvatech Company).
Fluorescence spectrum of light elements (from $\mathrm{Na}$ to $\mathrm{Cl}$ ) was recorded with additional blowing of the system by helium. For the elements with higher atomic number the spectrum was recorded without helium.

Fluorescence peaks of $\mathrm{K}$ and $\mathrm{Ca}$ are observed in both spectra due to the presence of high- and low-energy internal transitions in these elements.

The interpretation of the spectra was carried out taking into account the localization of the peaks that fall at the energy maximum of the electronic transition or the presence of all maxima of the characteristic transitions.

The quantitative composition was estimated using the device software by the method of deriving the ratios of the peak areas of each individual element to the total peak area of all elements according to the algorithm of fundamental parameters.

\section{Results and Discussion}

It is known from literature sources [14] that asphaltenes, which a part of bitumen, can interact with maleic anhydride via the Diels-Alder reaction:

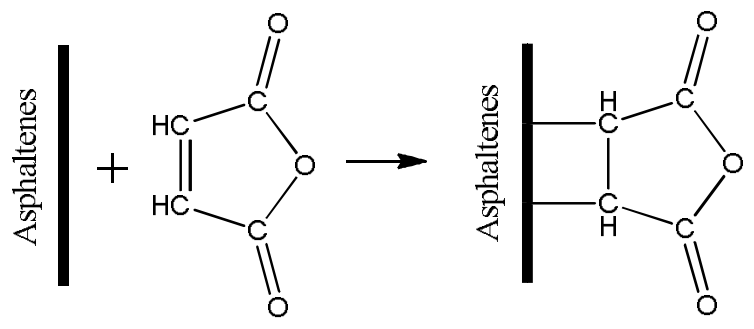

or through the formation of $\pi-\pi$ complexes:

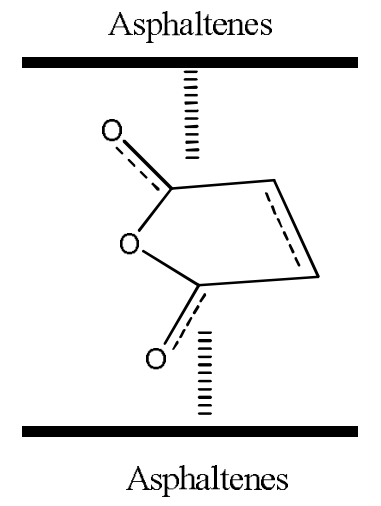

We studied the effect of the main factors (modifier amount, time and temperature) on the modification of bitumen with maleic anhydride. The effect of MAH amount is given in Table 5 .

The introduction of maleic anhydride up to $2 \mathrm{wt} \%$ increases the softening temperature of the modified bitumen (up to $325 \mathrm{~K}$ ). Further increase in the MAH amount practically does not change the softening 
temperature. Similar dependence is observed with another important index - adhesion to the crushed stone. This value increases from 2.5 to 4.5 points. The value of 4.5 points meets the requirements of current regulations for bitumen modified with adhesives, i.e. MAH modified bitumen does not need high-cost adhesive additives. Thus, the optimal amount of maleic anhydride for the modification of oxidized bitumen was found to be $2 \mathrm{wt} \%$.
The effect of the modification time is given in Table 6.

The results in Table 6 show that the modification process should be carried out for $30 \mathrm{~min}$. For this time the highest value of the softening temperature is reached.

The effect of temperature on the bitumen modification with maleic anhydride is presented in Table 7.

Table 4

Conditions for BO1 modification with maleic anhydride

\begin{tabular}{|c|c|}
\hline Index & Value \\
\hline Temperature, K & $403-443$ \\
\hline Time, min & $30-180$ \\
\hline $\begin{array}{c}\text { Maleic anhydride amount (value relative to the initial petroleum } \\
\text { residue), wt \% }\end{array}$ & $1-4$ \\
\hline
\end{tabular}

Table 5

Effect of MAH amount on the characteristics of the resulting products based on BO1

\begin{tabular}{|c|c|c|c|c|c|}
\hline Sample & $\begin{array}{c}\text { BO1 amount, } \\
\text { wt \% }\end{array}$ & $\begin{array}{c}\text { MAH amount, } \\
\text { wt \% }\end{array}$ & $\begin{array}{c}\text { Softening temperature } \\
(\text { R\&B), K }\end{array}$ & $\begin{array}{c}\text { Penetration at 298 K, } \\
0.1 \text { mm }\end{array}$ & $\begin{array}{c}\text { Adhesion to CS1 } \\
\text { surface, points }\end{array}$ \\
\hline BO1 & 100.0 & 0 & 319 & 71 & 2.5 \\
\hline BOMA-1 & 100.0 & 1 & 322 & 44 & 3.5 \\
\hline BOMA-2 & 100.0 & 2 & 325 & 34 & 4.5 \\
\hline BOMA-3 & 100.0 & 3 & 325 & 30 & 4.0 \\
\hline BOMA-4 & 100.0 & 4 & 326 & 31 & 4.5 \\
\hline
\end{tabular}

Note: process temperature is $423 \mathrm{~K}$; time is $60 \mathrm{~min}$.

Table 6

Effect of process time on the characteristics of the resulting products based on $\mathrm{BO}$

\begin{tabular}{|c|c|c|c|c|}
\hline Sample & Process time, min & $\begin{array}{c}\text { Softening temperature } \\
(\text { R\&B), K }\end{array}$ & $\begin{array}{c}\text { Penetration at 298 K, } \\
0.1 \mathrm{~mm}\end{array}$ & $\begin{array}{c}\text { Adhesion to CS1 surface, } \\
\text { points }\end{array}$ \\
\hline BO-1 & - & 319 & 71 & 2.5 \\
\hline BOMA-5 & 15 & 323 & 40 & 3.5 \\
\hline BOMA-6 & 30 & 326 & 35 & 4.0 \\
\hline BOMA-7 & 60 & 325 & 34 & 4.5 \\
\hline BOMA-8 & 120 & 323 & 37 & 4.0 \\
\hline BOMA-9 & 180 & 324 & 35 & 4.0 \\
\hline
\end{tabular}

Note: process temperature is $423 \mathrm{~K}$; MAH amount is $2 \mathrm{wt} \%$

Table 7

Effect of temperature on the characteristics of the resulting products based on BO1

\begin{tabular}{|c|c|c|c|c|}
\hline Sample & Temperature, $\mathrm{K}$ & $\begin{array}{c}\text { Softening temperature } \\
(\mathrm{R} \& \mathrm{~B}), \mathrm{K}\end{array}$ & $\begin{array}{c}\text { Penetration at 298 K, } \\
0.1 \mathrm{~mm}\end{array}$ & $\begin{array}{c}\text { Adhesion to CS1 surface, } \\
\text { points }\end{array}$ \\
\hline BO-1 & - & 319 & 71 & 2.5 \\
\hline BOMA-10 & 403 & 333 & 27 & 4.0 \\
\hline BOMA-11 & 423 & 326 & 35 & 4.0 \\
\hline BOMA-12 & 443 & 325 & 32 & 4.0 \\
\hline
\end{tabular}

Note: process time is $30 \mathrm{~min}$; MAH amount is $2 \mathrm{wt} \%$ 
At a low modification temperature $(403 \mathrm{~K})$ there is a significant increase in the softening temperature - up to $333 \mathrm{~K}$. At higher modification temperatures ( 423 and $443 \mathrm{~K}$ ) bitumen with much lower heat resistance is obtained (softening temperatures are 326 and $325 \mathrm{~K}$, respectively). This indicates different ways of chemical reaction of maleic anhydride with the constituent components of oxidized bitumen at low modification temperatures $(403 \mathrm{~K})$, in comparison with high ones (423 and $443 \mathrm{~K}$ ).

To compare the heat resistance of the modified bitumen, obtained via modification at $403 \mathrm{~K}$ (BOMA-10) and $443 \mathrm{~K}$ (BOMA-12), these samples were heated by the RTFOT method (Table 8). The RTFOT heating temperature is $436 \mathrm{~K}$.

Table 8

\section{Changes in bitumen characteristics after RTFOT}

\begin{tabular}{|l|c|c|c|c|c|c|}
\hline \multirow{2}{*}{ Index } & \multicolumn{3}{|c|}{ Before RTFOT } & \multicolumn{3}{c|}{ After RTFOT } \\
\cline { 2 - 7 } & BO-1 & BOMA-10 & BOMA-12 & BO-1 & BOMA-10 & BOMA-12 \\
\hline Change in mass after RTFOT, wt \% & - & - & - & 0.03 & 0.23 & 0.55 \\
\hline Softening temperature (R\&B) after RTFOT, K & 319 & 333 & 325 & 325.2 & 325.4 & 328.2 \\
\hline Penetration at 298 K after RTFOT, 0.1mm & 71 & 27 & 32 & 55 & 38 & 35 \\
\hline$\Delta$ R\&B, K & - & - & - & 6.2 & -7.6 & 3.2 \\
\hline Residual penetration, \% & - & - & - & 77.5 & 140.7 & 109.4 \\
\hline
\end{tabular}

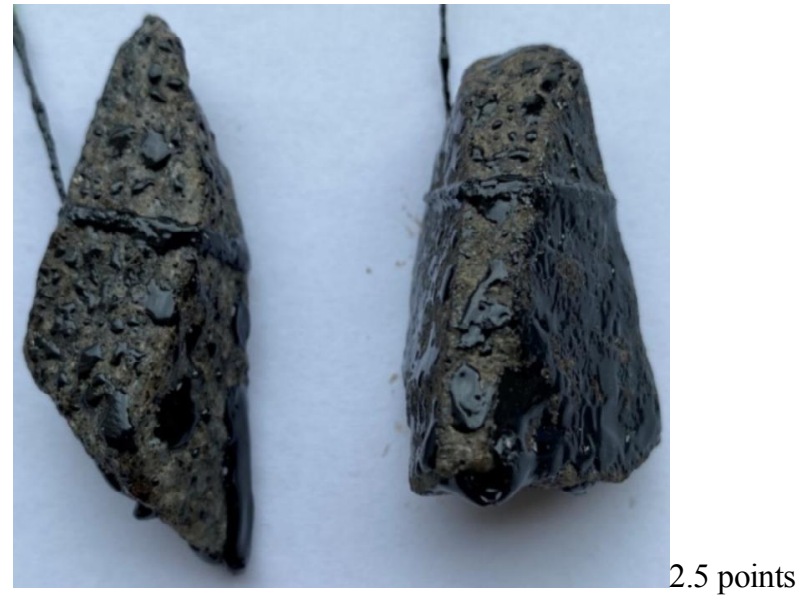

a)

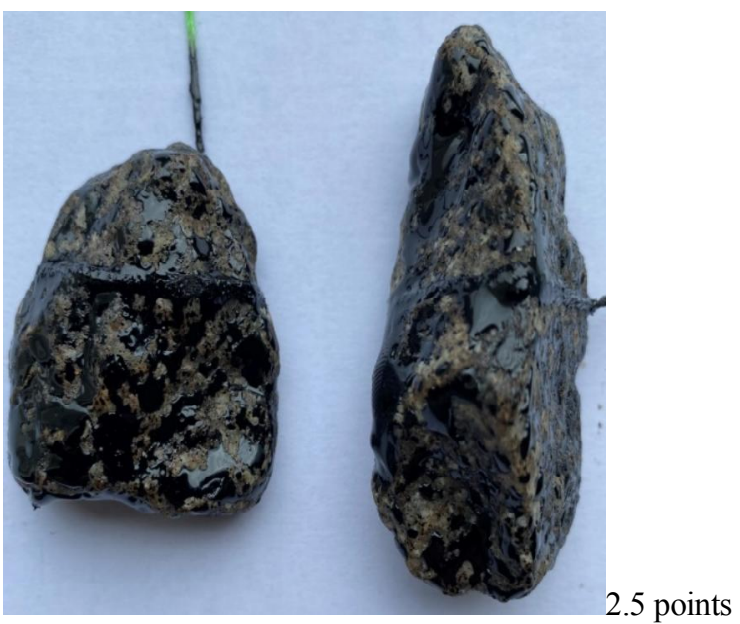

c)

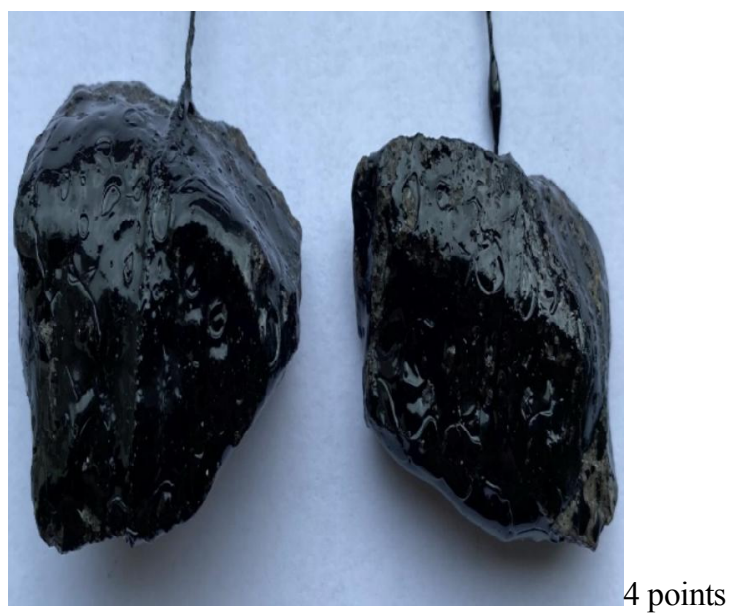

b)

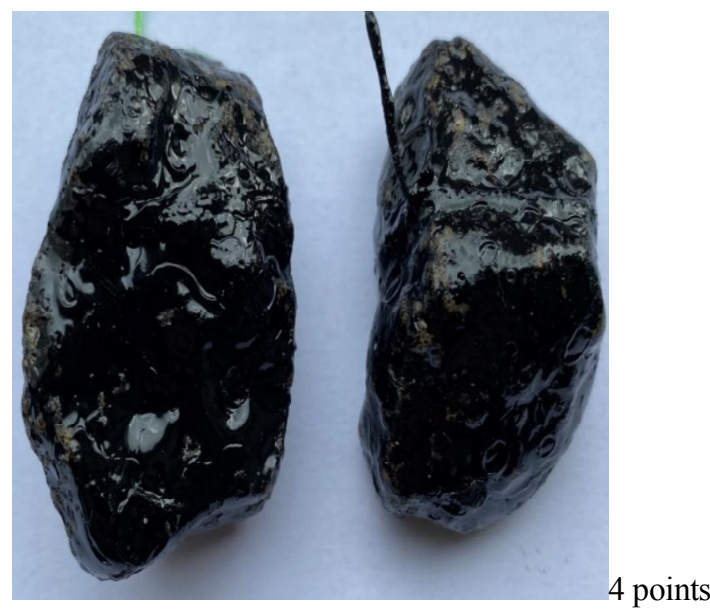

d)

Fig. 6. Adhesion to CS-1 (a, b) and CS2 (c, d) of unmodified BO-1 (a, c) and modified BOMA-10 (b, d) 
During the heating by RTFOT method an anomalous behavior is observed for BOMA-10, which was obtained by modification with maleic anhydride at the temperature of $403 \mathrm{~K}$. One can see a decrease in heat resistance (softening temperature decreases by $7.6 \mathrm{~K}$ ). For the comparison, the softening temperatures of BO-1 and BOMA-12 increase by 6.2 and $3.2 \mathrm{~K}$, respectively. Since the heating temperature of the RTFOT method is much higher than the obtaining temperature of BOMA-10 (cf. $436 \mathrm{~K}$ and $403 \mathrm{~K}$ ), the structure of the sample is destroyed under heating with a significant decrease in the heat resistance.

Therefore, to obtain a binder with great heat resistance, the modification of bitumen with maleic anhydride should be carried out at relatively low temperature $-403 \mathrm{~K}$. The increase in this temperature leads to the irreversible destruction of the formed structure. It should be taken into account that further temperature of asphalt mixtures preparation also should not exceed $403 \mathrm{~K}$, and this is a problem because most technologies for the preparation of asphalt mixtures take place at much higher temperatures. Therefore, the choice of the modification temperature is quite complex and requires a thorough approach.

The high adhesion properties of the obtained bitumen modified with maleic anhydride must be emphasized. Fig. 6 shows the adhesion of unmodified and modified bitumen (BOMA-10) to the surface of CS1 and CS2. The composition of crushed stones is given in subsection 2.1. For both samples the adhesion increases from 2.5 to 4.0 points.

The chemistry and mechanism of bitumen modification with maleic anhydride will be discussed in future publications.

\section{Conclusions}

It was found that the introduction of maleic anhydride (up to $2 \mathrm{wt} \%$ ) to the paving bitumen BND $60 / 90$ increases the softening temperature of the modified bitumen to $325 \mathrm{~K}$, and adhesion to the crushed stone (from 2.5 to 4.5 points). The process of bitumen modification with maleic anhydride should be carried out at a temperature of $403 \mathrm{~K}$ for 30 minutes. At higher temperatures ( 423 and $443 \mathrm{~K}$ ) bitumen with much lower heat resistance is obtained. Similar results were obtained when modifying bitumens at temperatures below $403 \mathrm{~K}$.

\section{Acknowledgements}

This work was supported by the National Research Foundation of Ukraine (Grant No. 2020.02/0038). Some experimental results were obtained in collaboration with
Laboratory of Advanced Technologies for the Creation and Physico-Chemical Analysis of New Compounds and Functional Materials of Lviv Polytechnic National University.

\section{References}

[1] https://bigbud.kmu.gov.ua/\#about

[2] Gunka V., Demchuk Y., Sidun I. et al.: Road Mater. Pavement

Des., 2020. https://doi.org/10.1080/14680629.2020.1808518

[3] Pyshyev S., Prysiazhnyi Y., Sidun I. et al.: Pet. Coal, 2020, 62, 341.

[4] Demchuk Y., Gunka V., Pyshyev S. et al.: Chem. Chem. Technol., 2020, 14, 251. https://doi.org/10.23939/chcht14.02.251

[5] Gunka V., Demchuk Yu., Pyshyev S. et al.: Pet. Coal, 2018, 60, 1199.

[6] Demchuk Y., Gunka V., Sidun I., Solodkyy S.: Proc. of EcoComfort, 2020, 95. https://doi.org/10.1007/978-3-030-57340-9_12

[7] Bratychak M., Gunka V., Prysiazhnyi Yu. et al.: Chem. Chem. Technol., 2021, 15, 274. https://doi.org/10.23939/chcht15.02.274

[8] Gunka V., Demchuk Y., Sidun I. et al.: Pet. Coal, 2020, 62, 420.

[9] Herrington P., Wu Y., Forbes M.: Fuel, 1999, 78, 101.

https://doi.org/10.1016/S0016-2361(98)00120-3

[10] Duty R., Liu H.: Fuel, 1980, 59, 546.

https://doi.org/10.1016/0016-2361(80)90230-6

[11] Zher'akova G., Kochkan'an R.: Fuel, 1990, 69, 898.

https://doi.org/10.1016/0016-2361(90)90239-M

[12] Nadkarni V., Shenoy A., Mathew J.: Ind. Eng. Chem. Prod. Res.

Dev. 1985, 24, 478. https://doi.org/10.1021/i300019a029

[13] DemchukYu., Sidun I., Gunka V. etal.: Chem. Chem. Technol., 2018, 12, 456. https://doi.org/10.23939/chcht12.04.456

[14] Kang Y., Wang F., Chen Z.: Chem. Eng. J., 2010, 164, 230.

https://doi.org/10.1016/j.cej.2010.08.020

[15] http://online.budstandart.com/ua/catalog/doc-

page.html?id_doc $=78299$

[16] http://online.budstandart.com/ua/catalog/doc-

page.html?id_doc $=78305$

[17] http://online.budstandart.com/ua/catalog/docpage.html?id_doc $=79270$

Received: December 28, 2020 / Revised: January 13, 2021 / Accepted: February 12, 2021

\section{ОДЕРЖАННЯ БІТУМУ, МОДИФІКОВАНОГО НИЗЬКОМОЛЕКУЛЯРНИМИ ОРГАНІЧНИМИ СПОЛУКАМИ ІЗ НАФТОВИХ ЗАЛИШКІВ. 2. МОДИФІКУВАННЯ БІТУМІВ МАЛЕЇНОВИМ АНГІДРИДОМ}

Анотація. Розглянута можливість модифікування бітуму марки БНД 60/90 виробничтва ПАТ Укртатнафта (Кременчук, Україна). Вивчено вплив кількості малеїнового ангідриду, тривалості процесу та температури на експлуатаиійні характеристики модифікованого бітуму.

Ключові слова: нафтові залишки, малеїновий ангідрид, модифіковані бітуми. 